\title{
Cyberbullying Among Secondary School Students
}

\author{
Y1lmaz BULUT* \\ Yıldız Teknik Üniversitesi, Eğitim Fakültesi, Eğitim Programları ve Öğretim Bölümü, \\ Beşiktaş / İstanbul / Türkiye

\section{Yrd. Doç. Dr. Bülent ALCI} \\ Yıldız Teknik Üniversitesi, Eğitim Fakültesi, Eğitim Programları ve Öğretim Bölümü, \\ Beşiktaş / İstanbul / Türkiye
}

\begin{abstract}
In this study, the prevalence of cyber bullying among secondary school students in Bagcilar was investigated. The study was conducted with 231 students studying at $7^{\text {th }}$ and $8^{\text {th }}$ grades in a sample secondary school in Istanbul, Turkey. The data were obtained through "Cyber Bullying Scale" and "Cyber Victimization Scale" developed by Arıcak, Kınay and Tanrikulu (2012). The results showed that getting unpleasant messages on the internet, saying things online that would not be said face to face, being disturbed via phone and introducing yourself as someone else were prevalent cyber bullying behaviors among secondary school students.
\end{abstract}

Keywords: Cyber bullying; Cyber victim; Cyber bully; Bullying on internet; Bullying via mobile. 


\section{Ortaokul Öğrencileri Arasındaki Siber Zorbalık}

\section{Özet}

$\mathrm{Bu}$ çalışmada, Bağcılar'daki ortaokul öğrencileri arasındaki siber zorbalığın yaygınlığı araştırılmıştır. Araştırma, İstanbul'daki örnek bir ortaokuldaki 7. ve 8. sınıfta okuyan 231 öğrenciyle yapılmıştır. Verilerin elde edilmesinde Arıcak, Kınay ve Tanrıkulu (2012) tarafindan geliştirilen "Siber Zorbalık Ölçeği" ve "Siber Mağduriyet Ölçeği" kullanılmıştır. Bulgular, internette hoş olmayan mesajlar alma, yüzüne karşı söyleyemediklerini söyleme, telefonla arayarak rahatsız edilme ve kendini başka birisi olarak tanıtma davranışlarının ortaokul öğrencileri arasındaki yaygın siber zorbalık davranışları olduğunu göstermiştir.

Anahtar Kelimeler: Siber zorbalık; Siber kurban; Siber zorba; İnternette zorbalık; Cep telefonunda zorbalık.

\section{Introduction}

Bullying both as traditional bullying and cyberbullying has drawn attention of many researchers in recent years (Antoniadou, 2013; Bayar and Uçanok, 2012; Çetinkaya, 2010; Hinduja and Patchin, 2010). Bullying exists in the schools or online. However, the way how bullying occurs and the effects of traditional bullying and cyberbullying can be different. Therefore, how cyberbullying is different from traditional should be distinguished first.

Traditional bullying means "malicious attempts to humiliate an individual" (Di Martino, 2003, p.2) and it also includes disturbing another person physically, verbally and psychologically (Nansel, Overpeck, Pilla, Ruan, Simons-Morton and Scheidt, 2001). Traditional bullying can also be defined as "aggressive behaviors or intentional 
harm by one person or a group, generally carried out repeatedly and over time, and involves a power differential" (Nansel et al., 2001). Traditional bullying was studied by many researchers but cyberbullying is not known well enough.

Smith, Mahdavi, Carvalho, Fisher, Russell and Tippett (2008, p.376) defines cyber-bullying is "an aggressive, intentional act carried out by a group or individual, using electronic forms of contact, repeatedly and over time against a victim who cannot easily defend himself or herself".

Cyberbullying occurs mostly through two electronic devices: computers and mobile phones (Patchin and Hinduja, 2006). Cyber bullies threaten, harass, embarrass or exclude victims by using those electronic devices (Mishna, McLuckie and Saini, 2009). The use of internet and the technological devices increased and young people started to use social networking websites, web cameras and instant messaging. Therefore, they began to have different experiences out of their schools and homes (Mishna, McLuckie and Saini, 2009).

Joinson (1998) argues that people in cyberspace behave in a way they do not in real life because of the effects of disinhibition. Disinhibition means the situation that behaviors are not restrained (Mason, 2008). Similarly, Suler (2004) states that people behave in a different way on internet comparing with their face-to-face communication since they are not restrained. In cyberspace, people do not use the social, affective or contextual sings as much as they use in face-to-face 
communication. Therefore, they become less sensitive and less regretful for the cyber bullying behaviors that they perform (Mason, 2008).

In cyberbullying, perpetrators have no direct social disapproval and punishment for engaging in bullying others and they also do not see that victims suffer (Willard, 2007). As a result, their behaviors are often disinhibited and become ruder, harsher, and more difficult to control (Hinduja and Patchin, 2009). As a result of this, victims can get damaged mentally and academically (Antoniadou, 2013). Furthermore, victims may even think about committing suicide. According to the results of the research in the United States, the number of cyberbullying victims who attempted suicide was nearly twice compared to youth who did not experience cyberbullying (Hinduja and Patchin, 2010).

There are several research abroad and in Turkey. They are mostly about the cyberbullying among high school students. However, there is a limited research on cyberbullying among secondary school students in Turkey. Therefore, further research should be carried out in order to examine the cyberbullying. With this regard, the purpose of study is to investigate the prevalence of cyberbullying among secondary school students in Bagcilar where is the most cosmopolitan area in Istanbul. More specifically, in this research, the answers of the questions below are searched;

1- What are the most typical cyberbullying behaviors?

2- Where does cyber bullying mostly happen? 


\section{Literature Review}

There are limited research about cyberbullying in Turkey but the number of the research is increasing gradually. Şahin, Sarı, Özer and Er (2010) conducted a quantitative research with 12 high school students in Trabzon. The results of the research revealed that cyberbullying is more common among male students compared to females and the most widespread cyberbullying behavior is disturbing by calling with a private number.

According to the results of the research carried out with 269 secondary school students by Aricak et al. (2008), $35.7 \%$ of the participants were cyber bully, $5.5 \%$ of the students were cyber victim and $23.8 \%$ of them were both bully and victim. It was also found that male students showed more bully, victim and bully-victim behaviors than female students. In addition, $25 \%$ of the victims stated that they informed their peers and parents about the cyberbullying while $30.6 \%$ of them stated they tried active solutions such as blocking the bully.

Likewise, Aydoğan, Dilmaç and Deniz (2009) made a research with secondary school students and the results of the is research showed that $32.6 \%$ of the secondary school students became cyber victim and $22.5 \%$ exhibited cyber bullying behaviors. Additionally, Ayas (2011) found that $17.4 \%$ of the high school students were exposed to cyber bullying and $15.5 \%$ of them showed cyber bullying behaviors.

According to the results of the research of Bayar and Uçanok (2012) conducted with 1263 secondary school and high school stu- 
dents, students who were not involved in traditional and cyber bullying perceived their school and teachers more positively than bullies and bully-victims.

Baker and Kavşut (2007) carried out a research with 228 high school students and $28 \%$ of the students were found to be cyber bully and $30 \%$ were cyber victims. The results showed that high school students in Turkey were tend to cyberbullying. It was also found that male students not only cyberbully more than girls but also they were exposed to cyberbullying more than girls.

The results of the research of Özdemir and Akar (2011) conducted on cyber bullying with 336 high school students revealed that $14 \%$ of the students were exposed to cyberbullying and $10 \%$ of them cyberbullied during previous month. It was also found that the most common cyberbullying place is a social sharing site "Facebook" and mobile phones are the mostly used devices for cyberbullying. In addition, Ekşi (2012) conducted a research with 508 vocational high school students and the findings revealed that narcissism has an indirect effect of cyberbullying.

Dilmaç (2009) made a research with 666 university students and the results showed that $22,5 \%$ of the university students cyberbullied and 55,3\% were exposed to cyber bullying at least once during their lifetime. Additionally, male students were found to be cyber bully more than females. Similarly, Arıcak (2009) conducted a research with 695 university students and found that $20 \%$ of the students cyber bullied at 
least one time and $54 \%$ of them were victims of cyber bullying. The result also revealed that nearly half of the participants pretended to be someone else on the internet or cell phone at least one time.

\section{Method}

\section{Design}

This study employed a quantitative methodology. Creswell (2012) states that quantitative research is used to collect data from a large number of people using predetermined instruments in order to describe a research problem. Convenience sample was used to choose participants.

\section{Participants}

This descriptive study were carried out with 231 students who attend to $7^{\text {th }}$ and $8^{\text {th }}$ grades at a secondary school in Bagcilar district of Istanbul during 2013-2014 academic year.

Table 1. The Participants

\begin{tabular}{lccc}
\hline Gender & ${\mathbf{7}^{\text {th }}}^{\text {grade }}$ & $\mathbf{8}^{\text {th }}$ grade & Total $(\mathbf{n})$ \\
\hline Male & 57 & 53 & 110 \\
Female & 58 & 63 & 121 \\
Total & 115 & 116 & 231 \\
\hline
\end{tabular}

110 of the participants $(47.6 \%)$ were male and 121 of them $(52.4$ $\%$ ) were female and they were 12-14 year-old. In addition, 115 of the participants were $7^{\text {th }}$ grade and 116 of them were $8^{\text {th }}$ grade students. Purposive sampling was used to choose the students. 


\section{Procedure}

The aim of the research is to determine the prevalence of cyber bullying that students practiced and experienced. Therefore, participants were asked to fill in a questionnaire in their classrooms in order to explore the frequency of cyber bullying behaviors which are experienced by students as both bullies and victims. Students were informed about the aims of the study and volunteer students were asked to take part in the research.

\section{Instrument}

Cyber Bullying Scale and Cyber Victimization Scale (Arıcak, Tanrıkulu and Kınay; 2012) and a brief demographic information form including questions about participants' gender, age and grade level were used.

The first part of the scale was personal information form, the second part involved 24 questions about the cyber bullying and the third part included 24 questions related to cyber victimization. 4 point likert scale was used to determine the frequency of cyber bullying behaviors and the scale included those four points: "never", "sometimes", "often", "always". In order to determine cyber victimization, yes / no type questions were used. The variance of the cyber bullying scale was found to be $50.58 \%$ and Cronbach alpha value was .95. Similarly, Cronbach alpha value of the cyber victim scale was .89 and the variance was $30.17 \%$. 


\section{Data Collection}

The participants were informed briefly about the cyber bullying and the aim of the study and they were also assured about anonymity and confidentiality before they filled in the questionnaire. Verbal consent was obtained from the students and they were asked to answer the questionnaire truthfully. The survey lasted approximately $30 \mathrm{mi}-$ nutes in each class and the data was collected in May, 2014 by the researcher. Data collection lasted four days.

\section{Data Analysis}

In order to investigate the prevalence and types of cyber bullying and cyber victimization, frequency analyses were performed. For data collection, the Statistical Package for Social Sciences (SPSS 20.0) was used.

\section{Results}

$52.4 \%$ of the participants are female and $47.6 \%$ of them are male. $6.5 \%$ of the participants are 12 years old, $45.5 \%$ of them are 13 years old and $48.0 \%$ of them are 14 years old and above. $49.8 \%$ of the participants attend seventh grade and $50.2 \%$ of them attend eighth grade.

According to the results of the study, $21.2 \%$ of the students surf on the internet for one hour, $22.1 \%$ surf for two hours, $16.5 \%$ for three hours and $11.7 \%$ for four hours. $21.6 \%$ of the students use internet for five hours and more. $6.9 \%$ of the students reported that they do not surf daily on the internet. 
The results showed that $51.1 \%$ of the students do not use computer daily without internet. $26.8 \%$ of the students use computer daily for one hour, $7.4 \%$ use computer for two hours, $3.9 \%$ use computer for three hours, $3.0 \%$ use computer for four hours and $7.8 \%$ use computer for five hours and more.

Table 2. The Purpose of Using İnternet

\begin{tabular}{lccc}
\hline Purpose & Male \% & Female \% & Total\% \\
\hline Study/do homework & 60.9 & 77.7 & 69.7 \\
Watch film & 42.7 & 47.1 & 45.0 \\
Social networking websites & 87.3 & 74.4 & 80.5 \\
Play games & 66.4 & 28.9 & 46.8 \\
Do shopping & 3.60 & 5.00 & 4.30 \\
Download/listen to music & 36.4 & 51.2 & 44.2 \\
Send/check e-mails & 10.9 & 5.0 & 7.8 \\
Get the news & 14.5 & 14.0 & 14.3 \\
\hline
\end{tabular}

The results related to the purposes of using internet revealed that $80.5 \%$ of the students use internet mostly for social networking websites. $69.7 \%$ of the students reported that they use internet for studying or for doing homework. $46.8 \%$ of the students play games and $45.0 \%$ watch films on the internet. While $44.2 \%$ of the students listen to music on the net, $14.3 \%$ use internet to get the news. $7.8 \%$ of the students use internet for sending or checking e-mails and $4.3 \%$ of the students do shopping online.

The results related to gender difference showed that $87.3 \%$ of the male students use internet daily for social networking sites, $66.4 \%$ play games on the internet and $60.9 \%$ do homework or study. However, it 
was found that most of the female students $(77.7 \%)$ use internet for doing homework or studying lesson. $74.4 \%$ use internet for social networking websites and $51.2 \%$ use internet for listening to music.

In addition, while $83.5 \%$ of the students were found to use facebook as a social networking website, $6.1 \%$ were found to use twitter. $10.4 \%$ of the students reported that they do not use any social networking sites.

According to the results of the study, $33.3 \%$ of the students introduced themselves as someone else on the internet. $23.8 \%$ of the students opened an e-mail account using the name of someone else and $18.6 \%$ opened a social networking account using the name of someone else. $15.2 \%$ of the students reported that they use their friend's password secretly and $12.6 \%$ used personal information of someone else on the internet.

$42.9 \%$ of the students stated that on the internet or mobile phones, they can easily tell the things that they can never tell face to face. While $19.5 \%$ of the students sent unpleasant messages to their friends, $16.9 \%$ sent insulting messages on the internet. Furthermore, $12.6 \%$ of the students sent threatening messages on the internet. While $8.2 \%$ of the students sent unpleasant messages to their friends, $10 \%$ sent insulting messages through mobile phones. Moreover, $7.8 \%$ of the students sent threatening messages through mobile phones. $24.2 \%$ of the students also stated that they disturbed people by calling them. The results also showed that $10.4 \%$ of the students published unpleasant 
news about someone on the internet and $5.6 \%$ spread false rumors on the internet while $6.9 \%$ spread false rumors through mobile phones.

According to the results, $16 \%$ of the students sent photos of their friends as an e-mail or message on the internet while $12.1 \%$ sent photos of their friends without permission via mobile phones. It was also found that $10 \%$ of the students published photos of their friends or someone else without their consent on the various websites.

$33.3 \%$ of the students stated that they called people bad names on the internet and $25.5 \%$ of the students teased another person on the internet while $13.9 \%$ teased another person through mobile phones.

Table 3. Common Cyber Bullying Behaviors Experienced by Victims

\section{Cyber bullying behaviors}

Getting unpleasant messages on the internet

Saying things online that would not be said face to face

Getting disturbed via phone

Introducing oneself as someone else

Opening an e-mail account using their names

Getting insulting messages

Using someone's password

Opening an social networking account using their names

Attempt to enter someone's account

Name-calling

Getting threats

\section{Percentage} 45.9

28.6

26.8

26.0

25.1

20.3

21.6

19.5 
According to the results about cyber-victimization, $28.6 \%$ of the students reported that someone opened an e-mail account using their names and $25.1 \%$ reported someone opened an social networking account such as facebook and twitter using their names. $26 \%$ reported that their passwords were used by another person and $20.3 \%$ reported someone attempted to enter their account secretly.

In addition, $43.3 \%$ of the students reported that they were said things online that would not be said face to face. $21.6 \%$ of the students were found to be exposed to name-calling on the internet and $39 \%$ reported that they were disturbed via phone.

Table 4. Cyber Bullying Behaviors on The Internet and Via Mobile Phones

\begin{tabular}{lcc}
\hline Cyber bullying behaviors & $\begin{array}{c}\text { On the } \\
\text { internet \% }\end{array}$ & $\begin{array}{c}\text { Via mobile } \\
\text { phones \% }\end{array}$ \\
\hline Getting unpleasant message & 45.9 & 15.6 \\
Being insulted & 26.8 & 10 \\
Being threatened & 19.5 & 9.1 \\
Being teased & 18.6 & 8.2 \\
Spreading rumors & 17.7 & 7.8 \\
Pictures sent by someone without permission & 10.8 & 6.9 \\
\hline
\end{tabular}

Students were found to be exposed cyber-bullying both on the internet and on the mobile phone. The findings demonstrated that 19.5 $\%$ of the students were threatened on the internet and $9.1 \%$ received threatening messages through mobile phones. $45.9 \%$ of the students got unpleasant messages on the internet while $15.6 \%$ got unpleasant 
messages through mobile phones. $10.8 \%$ stated that someone published their photos on some websites and $8.2 \%$ reported their photos were sent as an e-mail without permission while $6.9 \%$ stated their photos were sent to other people through mobile phones.

Additionally, $17.7 \%$ of the students reported that someone spread false rumors about them on the internet while $7.8 \%$ stated someone spread false rumors about them via mobile phones. Also, $26.8 \%$ of the students received insulting messages on the internet and $10 \%$ got insulting messages on the mobile phone. Moreover, some people teased $18.6 \%$ of the students on the internet and $8.2 \%$ of the students on the mobile phone.

\section{Discussion}

In this research, the prevalence of cyber bullying and common cyber bullying behaviors were examined. The results showed that secondary school students were exposed to various cyber bullying behaviors.

According to the results, nearly half of the students (49.8\%) use internet daily more than 2 hours a day. Students were found to surf on the internet averagely 2.97 hours a day. Özbay (2013) similarly found that students surf on the net averagely 2.79 hours.

There results showed that more than half of the male students use internet for social networking websites, for playing games and for studying or doing homework. Likewise, more than half of the female students use internet for studying lesson or doing homework, for social 
networking websites and for listening to music.

The most prevalent cyber bullying behaviors that students experienced were getting unpleasant messages on the internet, saying things online that would not be said face to face, being disturbed via phone and introducing yourself as someone else. Arıcak et al. (2008) also found that saying things online that would not be said face to face was the most common cyber bullying behavior.

The results of the study revealed that $33.3 \%$ of the students introduced themselves as someone else on the internet. Similarly, Arıcak (2009) found that nearly half of the students pretended to be someone else on the internet. Also, Çetinkaya (2010) found that $25.2 \%$ of the secondary school students introduced themselves as somebody else.

The rate of exposure to various cyber bullying behaviors on the internet or via mobile phones was found to be lower or higher in different research. For instance, spreading rumors $(7.8 \%)$ on the internet were found to be common in this research. Aricak et al. (2008) found that spreading rumors $(14.7 \%)$ was more common among secondary school students. In contrary, Çetinkaya (2010) found that spreading rumors $(2.9 \%)$ was not very common.

Finally, cyber bullying through mobile phones were also found to be high in this research. The most widespread cyber bullying behavior via mobile phone was being disturbed (39 \%). Similarly, Şahin, Sarı, Özer and Er (2010) found that disturbing by calling with a private number was the most prevalent cyber bullying behavior. The other 
common cyber bullying behaviors via phone were getting unpleasant messages $(15.6 \%)$, getting insulting messages $(10 \%)$, receiving threatening messages $(9.1 \%)$, being teased $(8.2 \%)$ and spreading rumors (7.8\%). Likewise, Arıcak et al. (2008) found that being threatened (22.8\%), being insulted (20.2\%), spreading rumors (16.4\%) and being teased (13.9\%) via mobile phones are common cyber bullying behaviors. However, Çetinkaya (2010) found that being threatened (3.9\%) and getting hurtful messages $(3.5 \%)$ via mobile phone were not very common.

\section{Conclusion}

The research about cyber bullying among students is increasing day by day and the studies about cyber bullying have showed that cyberbullying is emerging as a problem among students. However, there is limited research in Turkey about cyber bullying and hence, this study aimed to describe the common cyberbullying behaviors among secondary school students.

The findings of this study showed that secondary school students experience different cyber bullying behaviors. Getting unpleasant messages on the internet, saying things online that would not be said face to face, being disturbed via phone and introducing yourself as someone else are the most prevalent cyber bullying behaviors. In addition, students experience cyber bullying both on the internet and via mobile phone.

The participants of this study do not represent all secondary 
school students. Further research can be carried out with a larger group from different types of school. In addition, the views of teachers, school administrators and parents can be included and qualitative designs can be used to get information in depth for further research.

\section{References}

Antoniadou, N. (2013). Cyberbullying, personality and coping among pre-adolescents. International Journal of Cyber Behavior, Psychology and Learning, 3(4), 55-69.

Arıcak, T., Siyahhan, S., Uzunhasanoglu, A., Sarıbeyoglu, S., Ciplak, S., Y1lmaz, N. \& Memmedov, C. (2008). Cyberbullying among Turkish adolescents. CyberPsychology \& Behavior, 11(3), 253-261.

Arıcak, O. T. (2009). Psychiatric symptomatology as a predictor of cyberbullying among university students. Eurasian Journal of Educational Research, 34, 167-184.

Arıcak, O. T., Kınay, H. \& Tanrıkulu, T. (2012). Siber zorbalık ölçeği'nin ilk psikometrik bulguları. Hasan Âli Yücel Ĕ̆itim Fakültesi Dergisi, 17(1), 101-114.

Ayas, T. (2011). Lise ögrencilerinin sanal zorba ve mă̆dur olma yaygınlığı. XI. Ulusal Psikolojik Danışma ve Rehberlik Kongresi'nde sunulan bildiri. İzmir, 3-5 Ekim.

Aydoğan, D., Dilmaç, B. \& Deniz, M. E. (2009). Illköğretim öğrencilerinde sosyal destek ve siber zorbalı̆̆ın incelenmesi. 18. Ulusal Eğitim Bilimleri Kurultayı'nda sunulan bildiri. İzmir, 1-3 Ekim.

Baker, Ö. E. \& Kavşut, F. (2007). Akran zorbalığının yeni yüzü: Siber zorbal1k. Eurasian Journal of Educational Research, 27, 31-42. 
Bayar, Y. \& Uçanok, Z. (2012). School social climate and generalized peer perception in traditional and cyberbullying status. Educational Sciences: Theory \& Practice, 12(4), 2337-2358.

Creswell, J. W. (2012). Educational research: Planning, conducting and evaluating quantitative and qualitative research $\left(4^{\text {th }} \mathrm{ed}\right.$.). Boston: Pearson.

Çetinkaya, B. (2010). Ilköğretim ikinci kademe öğrencilerinde siber zorbalı̆̆ın yaygınlı̆̆g. Yayınlanmamış yüksek lisans tezi, Selçuk Üniversitesi .

Di Martino, V. (2003). Relationship between work stress and workplace violence in the health sector. 12 Ekim 2013, http://www.who.int/violenceinjuryprevention/violence/interpers onal/WVstresspaper.pdf

Dilmaç, B. (2009). Sanal zorbalığı yordayan psikolojik ihtiyaçlar: Lisans öğrencileri için bir ön çalışma. Kuram ve Uygulamada Eğitim Bilimleri, 9(3), 1291-1325.

Ekşi, F. (2012). Examination of narcissistic personality traits' predicting level of internet addiction and cyber bullying through path analysis, Educational Sciences: Theory \& Practice, 12(3), 1694-1706.

Hinduja, S. \& Patchin, J. W. (2009). Bullying beyond the schoolyard: Preventing and responding to cyberbullying. Thousand Oaks, CA: Crown Press.

Hinduja, S. \& Patchin, J. W. (2010). Bullying, cyberbullying, and suicide. Archives of Suicide Research, 14(3), 206-221.

Joinson, A. (1998). Causes and implications of disinhibited behavior on the internet. In J. Gackenbach, (Ed.), Psychology and the internet: Intrapersonal, interpersonal, and transpersonal implications (pp. 43-60). San Diego, CA: Academic Press. 
Mason, K. (2008). Cyberbullying: A preliminary assessment for school personnel. Psychology in the Schools, 45, 323-348.

Mishna, F., McLuckie, A. \& Saini, M. (2009). Real-world dangers in an online reality: A qualitative study examining online relationships and cyber abuse. Social Work Research, 33(2), 107-118.

Nansel. T. R., Overpeck, M., Pilla, R. S., Ruan, W. J., Simons-Morton, B. \& Scheidt, P. (2001). Bullying behaviors among U.S. youth: Prevalence and associations with psychosocial adjustment. Journal of the American Medical Association, 285, 2094-2100.

Patchin, J. W. \& Hinduja, S. (2006). Bullies move beyond the schoolyard: A preliminary look at cyberbullying. Youth Violence and Juvenile Justice, 4(2), 148 - 169.

Özbay, A. (2013). Ergenlerde siber zorbalık, siber mă̆duriyet, aleksitimi ve öfke ifade etme biçimleri arasındaki ilişki. Yayınlanmamış yüksek lisans tezi, Fatih Üniversitesi.

Özdemir, M. \& Akar, F. (2011). Lise öğrencilerinin siber-zorbalığa ilişkin görüşlerinin bazı değişkenler bakımından incelenmesi. Kuram ve Uygulamada Eğitim Yönetimi, 17(4), 605-626.

Smith, P. K., Mahdavi, J., Carvalho, M., Fisher, S., Russell, S. \& Tippett, N. (2008). Cyberbullying: its nature and impact in secondary school pupils. Journal of Child Psychology and Psychiatry, 49(4), 376-385.

Suler, J. (2004). The online disinhibition effect. Cyberpsychology \& Behavior, 7(3), 321-326.

Şahin, M., Sarı, S. V., Özer, Ö. \& Er, S. H. (2010). Lise öğrencilerinin siber zorba davranışlarda bulunma ve maruz kalma durumlarına 
ilişkin görüşleri. Süleyman Demirel Üniversitesi Fen Edebiyat Fakültesi Sosyal Bilimler Dergisi, 21, 257-270.

Willard, N. (2007). Cyberbullying and cyber-threats: responding to the challenge of online social aggression, threats, and distress. Champaign, IL: Research Press. 